\title{
Same or Different Development Paths? A Comparative Study of the Large Cities and Regions in Hungary*
}

\begin{abstract}
According to specialist literature, the current development of agglomerations is by large urban areas evolving by the expansion and structural transition of larger urban zones, where "the formerly hierarchic division of settlements with a different size and role is replaced by horizontal cooperation, linking into a network" (Enyedi 2012, p. 17). The aim of the present paper is to examine, how equal the domestic large cities and their agglomeration can be considered by their development and competitiveness, and if there is an economic basis for them to cooperate horizontally in a network in the present case. The authors use different methodological approaches to examine the development and competitiveness of cities and their agglomeration, and spatial autocorrelation circumstances to model the economic base of outlined cooperation.
\end{abstract}

Keywords: cities, catchment areas, accessibility, development, competitiveness, spatial autocorrelation.

\section{Introduction}

In national and international scientific literature, highly significant findings have been published in recent years on the socio-economic relations of cities and their catchment areas. The statement is particularly noticeable in regards to the current development of the catchment areas in the metropolitan regions, which were created by the extension and internal structural transformation of the major agglomerations; the previous hierarchical arrangement is being replaced by the horizontal cooperation and networking of settlements of different sizes and roles, but of the same rank (Enyedi 2012, p. 17). The purpose of this present study is to examine how cities and their city-regions in Hungary can be regarded as equal from the point of view of development and competitiveness as well as if there are economic grounds for their horizontal cooperation and networking. Prior to the actual analysis, it is important to refer to the most relevant connections to the questions in the scientific literature.

a) Hungarian Central Statistical Office, 1024 Budapest, Keleti Károly utca 5-7., Hungary, E-mail: geza.toth@ksh.hu

b) University of Miskolc 3515 Miskolc-Egyetemváros, E-mail: regnzozo@uni-miskolc.hu

* During the writing of the study, the work of Géza Tóth was supported by the János Bolyai Research Scholarship of the Hungarian Academy of Sciences. 
Space is a term used for that which is connected to a settlement through a certain or a number of functions, as the catchment area of a given municipality. Function-based centre-periphery relations play a fundamental role in the spatial organisation of society (Benedek 2000). One of the first critical studies on catchment areas in Hungary was the two-part study of Pál Beluszky (1970) published in the periodical of Regional Statistics. $\mathrm{He}$ states in this study that central functions and services are delivered in the central settlement - in many cases a town - for the catchment area, this functional role is more significant than the sheer population size of the central settlement.

The importance of studying catchment areas and agglomerations as well as the outstanding role of relationships in cities, catchment areas and city regions is indicated by numerous researches and scientific analyses (inter alia OECD and ESPON studies). In addition, this topic is represented in many official documents, e.g. in the urban-oriented Leipzig Charter of the EU (2007):

"An equal partnership between cities and rural areas as well as between small-, medium-sized and large towns and cities within city-regions and metropolitan regions is the aim. We must stop looking at urban development policy issues and decisions at the level of each city in isolation. Our cities should be focal points of city-regional development and assume responsibility for territorial cohesion. It would, therefore, be helpful if our cities would network more closely with each other at European level."

As the scientific literature points out, successful economic areas are in the surroundings of major cities, but it does not mean that the success of the city region depends on the city (Dunford-Perrons 1994).

The catchment areas frequently overlap each other with the intensity of the effect of functions falling at different rates as the distance increases from the centre (Taylor 2004).

Concerning the relations between cities and their catchment areas, Coombes and Raybould (2004) pointed out that the smaller settlements of the commuter zones receive relocated jobs from central areas in more and more cases. In several states of Europe, the state bodies understood that city region oriented strategies are needed instead of focusing on the major cities assuming that coordinated developments promote development in the catchment areas (Adam 2003, Hoggart 2012); as proposed by the Leipzig Charter (2007).

Despite the close interrelatedness and mutual dependence between the city and its catchment area, unfortunately, the relationship is frequently subject to serious strains (Schuh-Sedlacek 2002).

There are several potential methods to delimit and analyse towns, cities and their catchment areas (Kovács 1987, Hajdú 1994, Mokos 1998, Győri 2000, Kovács 2002). Since the approach of this work is quite different from the previous ones, it only refers to those delimitation methods that are considered important based on the work of Norbert Bodor és János Pénzes (2012). Based on this, gravity models (Kiss-Bajmócy 2001, Pénzes 2005) and GIS devices can be distinguished among the deductive testing methods. There are empirical methods, such as the ankét method, the customer counting method, the evaluation of long-distance telephone calls.

A further option is to analyse how some stages of the agglomeration process take place in a major urban agglomeration instead of simply delimiting a catchment area. This is about analysing the real relationships between the main city and the attracted settlements to delimit major urban agglomerations (Kovács-Tóth 2003). 


\section{Description of the methods and objectives}

The purpose of the present study, for multiple reasons, is not to follow the previously described methods. On the one hand, no data is available for such delimitations as the data of the 2011 census (commuting, employment structure) were not available when the research was conducted. On the other, the authors did not wish to model real relationships while delimiting catchment areas, i.e. which settlement belongs to which central city based catchment area. In this regard, the authors believe that in certain areas of the country - as will be outlined in the study - some settlements are not only a hinterland of a great city, but may be related to more of them, fundamentally affecting the spatial structure of the country. It is possible to determine which centre attracts a given town in a stronger way, but it would be a very different approach for this analysis. The main purpose of the study is to show how similar or how different the major cities of Hungary are from their catchment areas in economic terms. A group of settlements was used that are in equal distance and time from the central city as a theoretical catchment area, i.e. an area from which the city attracts resources and on which the city exerts direct positive or negative economic influences. This approach is practically the same as the calculations determining the potential service area of a corporation. ${ }^{1}$ The comparison between centres and catchment areas is by no means unique in Hungarian scientific literature. In a slightly different approach, János Pénzes conducted and published a similar research on the spatial structure of north-eastern and north-western Hungary (2013).

Concerning single cities, the authors are aware that the real catchment areas are not the same as the settlements subject to the analysis. In most cases, they form only one part of the actual catchment area or in case of several major cities, especially in case of the capital city, the real catchment area is somewhat larger.

The aspects of accessibility were considered during the determination of theoretical catchment areas (hereinafter catchment areas). Specifically, those settlements, whose geometric centre is located 30 or 45 minutes by road from the geometric centre of the given central settlement, were grouped into the respective catchment area. The data of the settlements in the catchment area were totalled to calculate the required indicators. It also follows from this calculation method that it only gives an average value for the catchment areas, which necessarily blurs or may blur the regional differences among the affected settlements. This must be taken into account when evaluating the results.

Accessibility-based delimitation of the theoretical catchment areas, as opposed to the traditional frameworks, was chosen as a technique because when making sub-regional or district level studies, the examination would be bounded by the county borders in any case, which are often overlapped by the catchment area relationships. (Szalkai 2010). The study might have been carried out by using "functional urban areas" (Sütö 2008), but their delimitation still reflects the conditions of 2001; so it was considered that the current accessibility relations based delimitation could also highlight important

1 The calculations were performed by running Service Area calculations in the Network Analyst of the ESRI ArcGIS 10 software. 
relationships. A similar problem arises if the method of agglomeration delimitation is used. The study of Hajnalka Löcsei (2004) is a good example for this approach. The use of the accessibility analysis was only limited by the fact that only a nation-wide dataset was available, thus, it was not possible for to analyse cross-border catchment area relationships (see different approaches on this subject at Kovács 1990, Hardi 2008).

Although the results were also given for the group of settlements available within 45 minutes, the study focused on the group of settlements available within 30 minutes, as a closer relationship could be assumed in this case. When determining the minute-borders, it takes into account the findings of the international scientific literature according to which most travel to work journeys are shorter than 30 minutes even in such major metropolitan regions like Los Angeles (Giuliano-Small 1993). The study chose not to use the distance suggested by the results of the scientific literature, so calculations were carried out taking into account both 30 and 45 minute time frames. The need for such approaches is underlined by the fact that the size and growth potential of the urban markets are determined by the accessibility of their catchment areas (Muller 1977, p. 29).

Therefore, in this respect, the use of long-distance thresholds may be regarded as arbitrary; the study chose these as the boundaries, within which those settlements are situated, which are or can be in a meaningful relationship with the indicated central settlement. This is only a theoretical relationship, as it is possible that within the indicated distance thresholds or in some cases even beyond them there are such settlements, which can affect the central town and vice versa. With the different directional effects, it cannot be forgotten that next to the economic force of agglomeration (centripetal force), which facilitates city growth and the formation of spatial groupings, the repulsive force of the big city will appear as well. Thus, the advantages of this grouping are limited, because when transport costs increase, cheaper production costs can be suppressed (Haggett 2006). These tests were performed by using several methods.

Initially, the study tried to demonstrate the economic aspects of development by calculating per capita taxable incomes and unemployment rates. It is assumed that these two indicators clearly illustrate the spatial differences in development taking into account the current domestic relations. Although the use of other indices and indicators would be justifiable, these two indicators were used for the sake of simplicity. On the spatial structure of incomes, János Péter Kiss (2008) found that its size and changes are usually synchronized with the development of GDP. However, there are very significant differences in the spatial structure of GDP and that of incomes. Kiss also points out that the regional inequalities of incomes are smaller than that of GDP. Concerning the spatial pattern of unemployment, Hajnalka Löcsei (2010a) has identified that it has been relatively stable since the second half of the 1990s and essentially reflects the spatial structure of development. As Löcsei (2010b) also explains the area bounded by the capital city and its agglomeration, Lake Balaton, the region's motorways and the Austrian border area have the best unemployment figures. Inner periphery settlements situated east of an imaginary line connecting Balassagyarmat with Békéscsaba, outlying South Transdanubian and the north-eastern borders, as well as the Middle-Tisza area, are in the worst state.

This delimitation of the catchment areas results in the problem that the catchment areas overlap each other. This is certainly true in practice, although the paper does not try 
to delimit them in line with the effect intensity of the gravity method, i.e. the given settlement can even be in the catchment areas of several centres. There are even such cases (for example, Szeged, Hódmezővásárhely), when two centres are in the neighbourhood of each other. It is considered that the development of the given attracted settlement, may, on the one hand, be explained by its geographic location (i.e. which region of the country it lies in ), the position of the centre(s) attracting it as well as, in particular, by how many attraction centres are available within 30 minutes. The latter, of course, represents only a potential opportunity, the effect of which is difficult to measure. Nevertheless it must be considered.

Grouping of settlements by 30-minute catchment areas of major cities, 2011

Figure 1

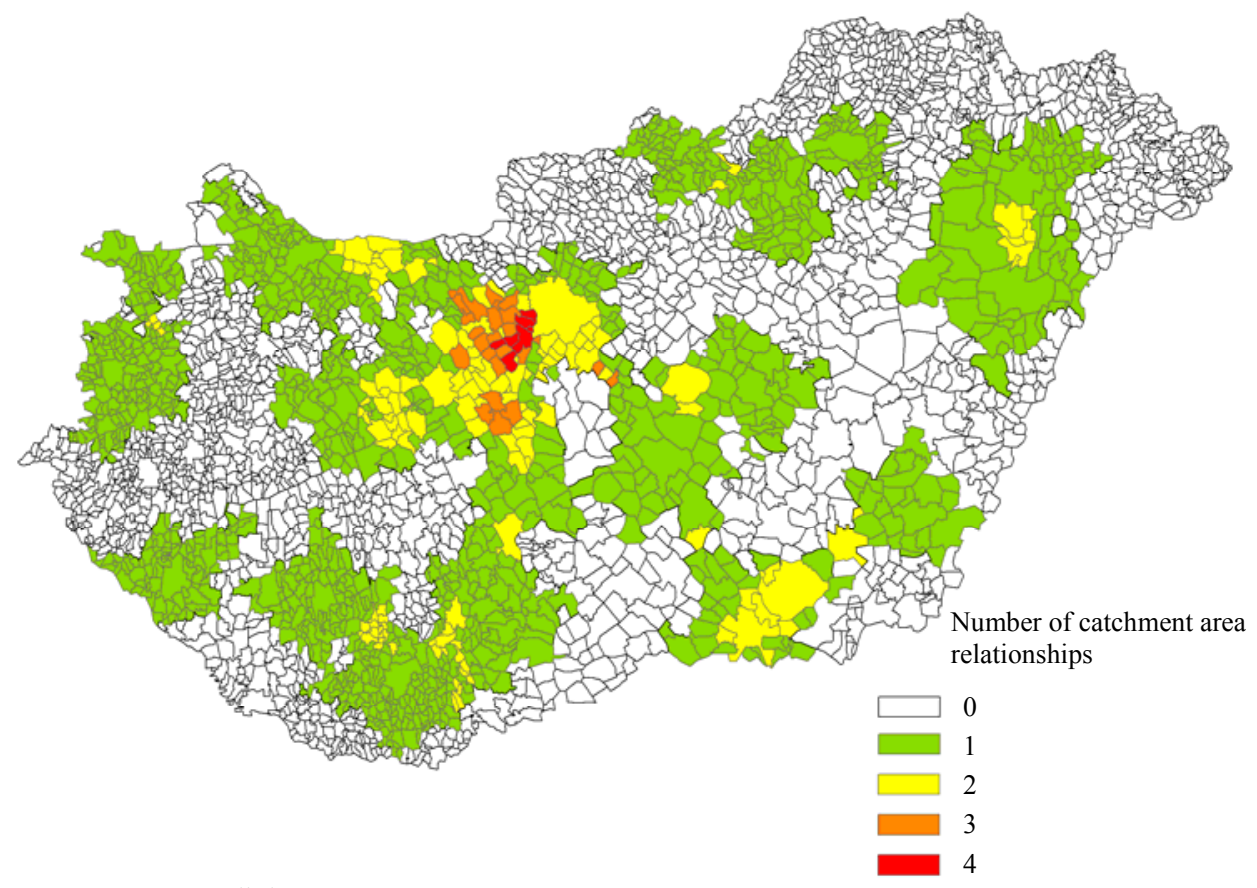

Source: Own compilation.

If we accept that the centre-catchment-area-relationship has a decisive importance in the spatial organisation of society, it is worth looking at what is the relationship between their economic strength. Put simply, how can the city and its surroundings mutually support each other or does the centre just drain the energy of the catchment area? The examination is about the economic basis of the potential links between the city and its environs. Of course, it is only one possible method to approach the relations between the city and its environs. The works of Viktória Szirmai $(2007,2009)$, taking into account the social factors, provide a good example for such assessments. 


\section{The development of cities and their catchment areas}

Based on 2011 data, in most cases - with the exception of three settlements - central cities always have a higher per capita income than their catchment areas. These exceptions are county towns, namely Érd, Tatabánya and Hódmezővásárhely; the other centre, which is significantly more developed than the local centre (at the former two it is Budapest, at the latter it is Szeged), is included in the catchment area because of the overlap between the catchment areas, causing the difference. Normally, the centres have an average value of about 20 percentage points higher than the average value of the settlements in the catchment area. Sopron slightly stands out from the income data of its catchment area while the largest difference can be seen in respect of Nyíregyháza. It is not surprising that Székesfehérvár and Budapest have the highest figures among central cities, nor the crucial role played by the Budapest agglomeration (It can be seen from the data of the catchment areas of Érd and Tatabánya).

Table 1

Per capita income in the studied settlements and their catchment areas as a percentage of the national average, 2011

\begin{tabular}{|c|c|c|c|}
\hline \multirow{2}{*}{ Capital city, county towns } & \multirow{2}{*}{ Central settlement } & 30-minute & 45-minute \\
\hline & & \multicolumn{2}{|c|}{ catchment areas } \\
\hline Békéscsaba & 96 & 81 & 78 \\
\hline Budapest & 133 & 124 & 113 \\
\hline Debrecen & 106 & 71 & 79 \\
\hline Dunaújváros & 126 & 113 & 123 \\
\hline Eger & 114 & 80 & 89 \\
\hline Érd & 120 & 130 & 124 \\
\hline Győr & 123 & 110 & 108 \\
\hline Hódmezővásárhely & 84 & 97 & 87 \\
\hline Kaposvár & 95 & 71 & 85 \\
\hline Kecskemét & 107 & 81 & 117 \\
\hline Miskolc & 100 & 88 & 83 \\
\hline Nagykanizsa & 106 & 75 & 88 \\
\hline Nyíregyháza & 104 & 67 & 81 \\
\hline Pécs & 100 & 79 & 82 \\
\hline Salgótarján & 93 & 72 & 83 \\
\hline Sopron & 90 & 88 & 102 \\
\hline Szeged & 102 & 76 & 85 \\
\hline Székesfehérvár & 135 & 113 & 124 \\
\hline Szekszárd & 121 & 89 & 90 \\
\hline Szolnok & 115 & 81 & 85 \\
\hline Szombathely & 117 & 102 & 99 \\
\hline Tatabánya & 110 & 122 & 128 \\
\hline Veszprém & 117 & 103 & 105 \\
\hline Zalaegerszeg & 113 & 91 & 97 \\
\hline Mean & 120 & 109 & 110 \\
\hline
\end{tabular}

Source: Own compilation.

Looking at changes over time, it can be seen that from 2001 to 2011 - with the exception of Érd - there was a greater shift in case of each catchment area than in the 
case of its centre. Concerning the centre and its catchment area, the average displacement difference was nearly 40 percentage points over the period of ten years. Within this, the catchment area of Dunaújváros shows the most significant shift compared to the centre. That is, the lower initial base catchment areas show a slightly faster growth than their centres. Nevertheless, the basic conditions, i.e. the relative maturity of the centre compared to the surrounding areas, continues to exist.

Regarding unemployment rates, the situation is similar to that of per capita incomes, as with the exception of Dunaújváros, Hódmezővásárhely and Tatabánya, the unemployment in the catchment area is always higher than in the central settlement. On average, the difference is two-percentage points. In this regard, the biggest differences are in Nyíregyháza, Debrecen and Eger (7.0, 6.1 and 5.0\% respectively).

Examining the temporal changes of the unemployment rate it can be generally stated, that in line with the national processes, there was a growth in all centres and catchment areas from 2001 to 2011. However, in the context of where unemployment increased further, in the centre or the catchment area, the picture is very mixed. There were 11 such centres (including Budapest), where the rise in unemployment was slower than in the centre during the analysed period, while 13 cases showed an opposite trend.

Table 2

Unemployment rate in the examined cities and catchment areas, 2011

\begin{tabular}{|c|c|c|c|}
\hline \multirow{3}{*}{ Capital city, county towns } & \multirow{3}{*}{ Central settlement } & 30 -minute & 45 -minute \\
\hline & & \multirow{2}{*}{\multicolumn{2}{|c|}{ catchment areas }} \\
\hline & & & \\
\hline Békéscsaba & 9.0 & 9.7 & 10.0 \\
\hline Budapest & 3.9 & 3.9 & 5.5 \\
\hline Debrecen & 8.6 & 14.5 & 13.2 \\
\hline Dunaújváros & 7.0 & 6.2 & 5.0 \\
\hline Eger & 6.9 & 11.9 & 12.1 \\
\hline Érd & 4.0 & 4.2 & 4.8 \\
\hline Győr & 4.3 & 4.7 & 5.3 \\
\hline Hódmezővásárhely & 6.5 & 6.3 & 7.8 \\
\hline Kaposvár & 8.0 & 12.4 & 10.5 \\
\hline Kecskemét & 7.5 & 8.2 & 5.3 \\
\hline Miskolc & 10.3 & 13.1 & 13.9 \\
\hline Nagykanizsa & 8.2 & 12.7 & 9.0 \\
\hline Nyíregyháza & 8.5 & 15.5 & 13.6 \\
\hline Pécs & 7.4 & 11.5 & 10.8 \\
\hline Salgótarján & 15.3 & 15.7 & 12.4 \\
\hline Sopron & 1.8 & 2.1 & 3.7 \\
\hline Szeged & 5.8 & 7.6 & 8.3 \\
\hline Székesfehérvár & 6.0 & 6.3 & 4.9 \\
\hline Szekszárd & 6.3 & 8.5 & 9.1 \\
\hline Szolnok & 7.5 & 9.9 & 9.5 \\
\hline Szombathely & 3.8 & 4.7 & 5.5 \\
\hline Tatabánya & 5.8 & 4.8 & 4.3 \\
\hline Veszprém & 5.4 & 7.0 & 7.4 \\
\hline Zalaegerszeg & 5.5 & 7.3 & 6.8 \\
\hline Mean & 5.6 & 6.6 & 6.7 \\
\hline
\end{tabular}

Source: Own compilation. 
The reasons may be quite complex in this matter. One explanation could come from the agglomeration processes; that is, among the highly educated population that moved into the catchment area (Forray-Hives 2009), the rise in unemployment is somewhat lower than in the centres, despite the rise in graduate unemployment that affects the highly educated population. This can be an explanation for the situation in Budapest although it is true that this study does not undertake the detailed exploration of the causes. The situation is completely different in a recessionary area such as in Békéscsaba and its surroundings. The biggest difference between the centre and the catchment area was recorded here in favour of the catchment area. In this case, the economic crisis exerted a stronger effect on the centre of the underdeveloped region than on the regionally and nationally less developed and more unemployment-stricken catchment area.

\section{Examination of competitiveness}

It is also worth considering the competitive position of a given town and catchment area. On the competitiveness of cities, several important studies were published in the scientific literature in Hungary (Lengyel 2003, Nemes Nagy 2004, Egedy 2012). In this study, the factorization method of Nemes Nagy (2004), who made calculations (formula 1) on domestic micro-regions and cities, is used:

$$
\begin{aligned}
& \frac{\text { Income }}{\text { Population }}=\frac{\text { Income }}{\text { Employees }} * \\
& \frac{\text { Employees }}{\text { Activeagepeople }} * \frac{\text { Activeagepeople }}{\text { Population }}
\end{aligned}
$$

In the measurements, 'earning' means earnings generated in a given settlement and subject to personal income tax liability, the number of employees means the number of taxpayers in a given year, people aged 18-59 are regarded as active age people while the 'population' stands for the number of permanent residents.

The income per taxpayer essentially approximates the productivity of the economy of each accessibility group. The proportion of taxpayers in the working age population gives a reasonable estimate for the employment level. However, the proportion of active age people in the population, which is a specific age structural indicator, indicates a potential workforce reserve due to the high proportion of working age people (Nemes Nagy 2004).

After some mathematical transformation (the logarithm of the values should be calculated), the multiplication is transformed into a much more manageable amount, according to the following formula (Formula 2):

$$
\begin{aligned}
& \log \left(\frac{\text { Income }}{\text { Population }}\right)=\log \left(\frac{\text { Income }}{\text { Employees }}\right)+ \\
& \log \left(\frac{\text { Employees }}{\text { Activeagepeople }}\right)+\log \left(\frac{\text { Activeagepeople }}{\text { Population }}\right)
\end{aligned}
$$

The outlined defactorisation was used for region typing. The logarithm was to compare the size of the different factors with each other. Based on these calculations - in accordance with the results of Nemes Nagy - it was found that productivity differentials are mainly behind the income differentials while the effect of the structural factors is very low. The 
basis of the typing is the relationship of the values of each city and catchment area, with the national average in case of the household incomes, as well as their underlying three factors. Taking his technical solutions, in Annex 1 and 2, the factors above the national average were labelled 1 and those below the average 0 (the first number is always the symbol of household incomes, while the second is that of productivity, the third is employment and the fourth is the structural factor). Areas with above average household incomes are considered to be competitively advantaged areas and those with below average incomes are considered to be competitively disadvantaged areas. Within this, a complex competitive advantage is detected if the area has above average values in all three components of household incomes while there is a multi- or single-factor competitive advantage if that condition is fulfilled in the case of only one or two factor(s). The nature of the competitive disadvantage is interpreted in the analogy of this (Figure 2,3). In the figures, the left signal always means the centres, while the right signal represents the 30-minute catchment area.

Based on the calculations performed on 2011 data, the differences were very significant in respect of the centre and its catchment area. Dunaújváros is in the best position since here the centre and the 30-kilometer catchment area have a complex competitive advantage. In the case of Budapest, Érd, Győr, Székesfehérvár, Szombathely, Tatabánya and Veszprém, both the centre and the catchment area are competitive on the basis of one of the underlying factors. In contrast to this, Debrecen, Eger, Kecskemét, Miskolc, Nagykanizsa, Nyíregyháza, Pécs, Szeged, Szekszárd, Szolnok and Zalaegerszeg show such examples, where the competitive centres are surrounded by competitively disadvantaged catchment areas. Békéscsaba, Hódmezővásárhely, Kaposvár, Salgótarján and Sopron are such cities where both the centre and the catchment area are competitively disadvantaged.

In respect of the change between 2001 and 2011, the situation is different since there is no such city where the change in both the centre and the catchment area would be competitive in a complex way compared to the national average. In the case of Miskolc, Nyíregyháza and Tatabanya, it can be seen that both the centre and the catchment area showed one of the types of competitiveness during the transformation. Érd is the only city where the centre is competitive, but the surrounding areas are competitively disadvantaged. Concerning the vast majority of cities, to be more precise in the case of 16 great cities, the combination of a competitively disadvantaged centre and a competitively advantaged catchment area is typical. As for Hódmezővásárhely, Sopron, Szombathely and Szekszárd, in the indicated period, the changes negatively affected the competitiveness of both the city and its catchment area. 


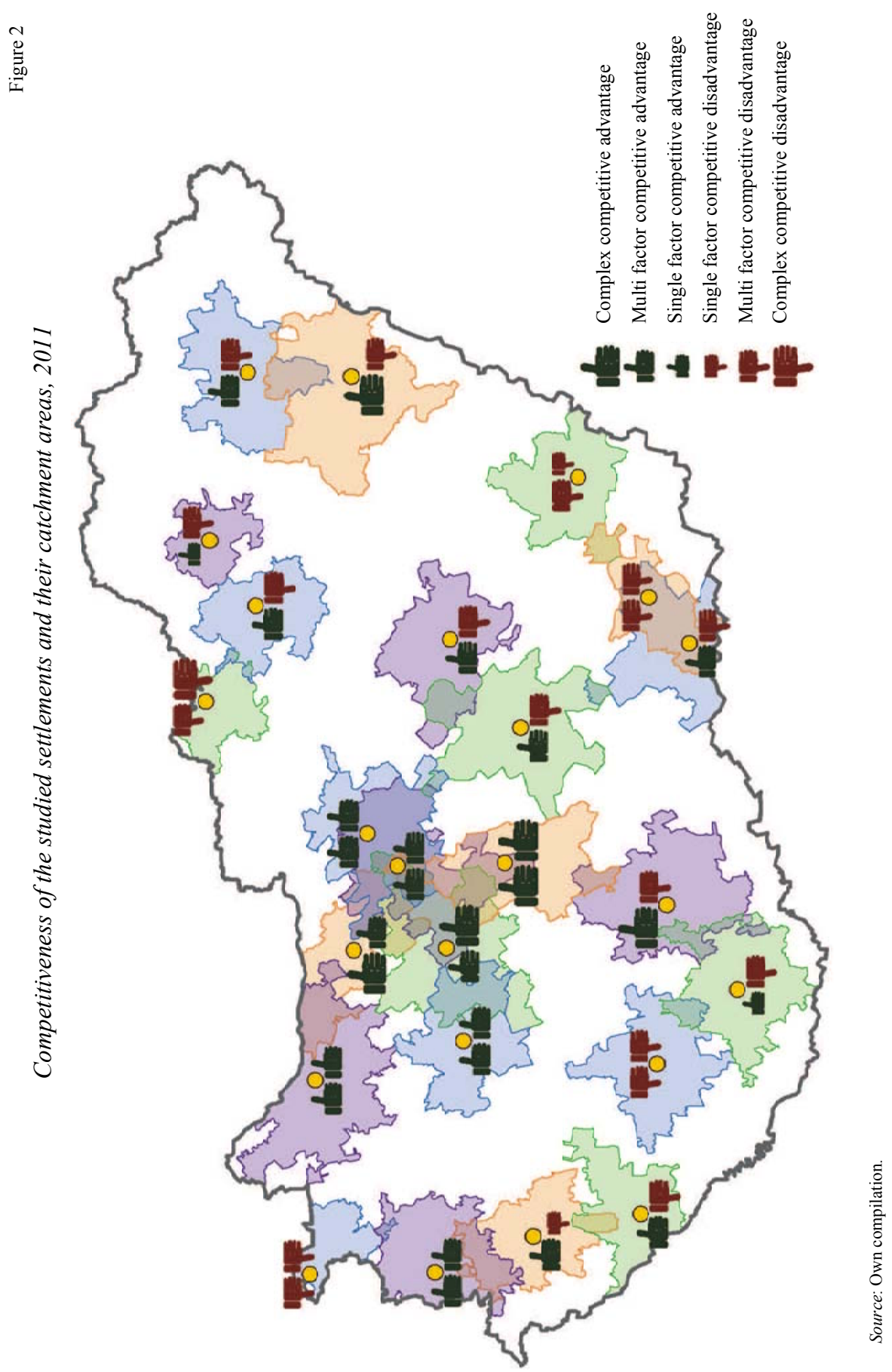




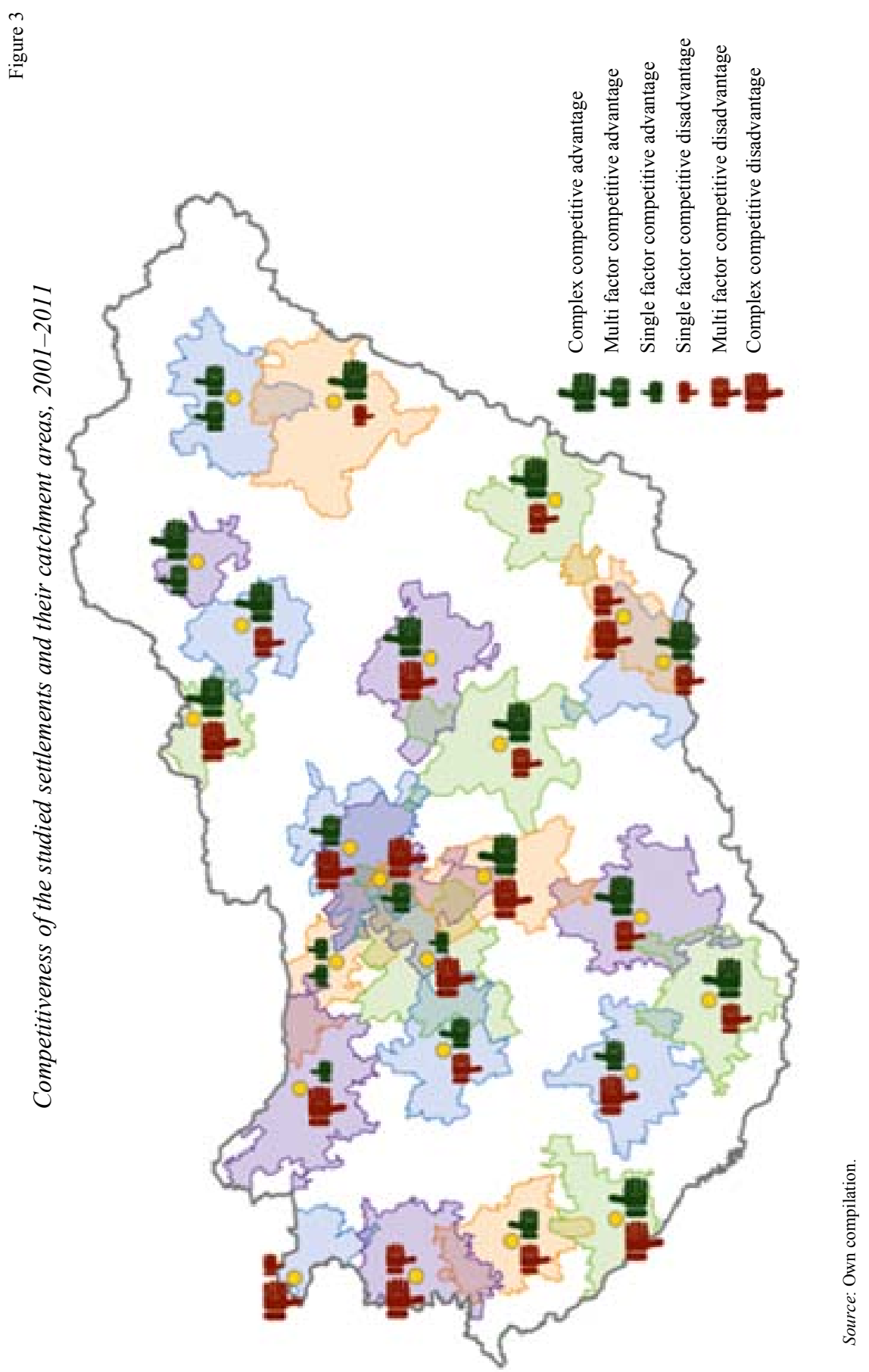




\section{Spatial autocorrelation analysis}

After presenting the process and competitiveness indicators, the spatial relationships are examined, which are partly due to the interplay of the above-mentioned factors, from the aspect of spatial autocorrelation. The research of spatial autocorrelation, which is often only called LISA (Local Indicators of Spatial Association) in the international scientific literature, started following the path breaking work of Luc Anselin (1995). Local autocorrelation indices have been already used by several studies in Hungary (Tóth 2003, Bálint 2011, Tóth-Kincses 2011). With the introduction of Moran's I, Luc Anselin (1995) developed the Local Moran's I statistic, which is one of the most commonly used methods to quantify and visualize spatial autocorrelation; in the paper, it is used to explore the spatial economic relations of large cities. Using the designation (1996) of Getis and Ord, I is defined as (Formula 3):

$$
I_{i}=\frac{\left(Z_{i}-\overline{Z)}\right.}{S_{z}^{2}} * \sum_{j=1}^{N}\left[W_{i j}^{*}\left(Z_{i}-\bar{Z}\right)\right],
$$

where $Z$ is the average of all units, $Z_{i}$ is the value of unit $I, S_{z}^{2}$ is the dispersion of variable $z$ for all observed units and $\mathrm{W}_{\mathrm{ij}}$ is the distance weighting factor between $\mathrm{i}$ and $\mathrm{j}$ units, which comes from the $\mathrm{W}_{\mathrm{ij}}$ neighbourhood matrix (basically $\mathrm{W}_{\mathrm{ij}}=1$ if $\mathrm{i}$ and $\mathrm{j}$ are neighbours and 0 if they are not).

Using the Local Moran's I value, the negative values mean a negative autocorrelation and the positive ones a positive autocorrelation. At the same time, the function has a wider range of values than the interval of $-1 ;+1$. The indicator also has a standardised version, but at this time it is not dealt with. The Local Moran statistics are suitable to show the areas that are similar to or different from their neighbours. The bigger the Local Moran I value, the closer the spatial similarity. However, in case of negative values, it can be concluded that the spatial distribution of the variables is close to a random distribution. Concerning the Local Moran I, the calculations were carried for the per capita income and the unemployment rate at municipal level for 2001 and 2011. During the work, the results of the Local Moran statistic were compared with the initial data in order to be able to examine whether the high degree of similarity is caused by the concentration of the high or low values of the variable (Moran Scatterplots). As a first step, on the horizontal axis of the graph the standardised values of the observation units were plotted, while on the y-axis the corresponding standardised Local Moran's I values (average neighbour values) were plotted. The scatterplot puts the municipalities into four groups according to their location in the particular quarters of the plane: value.

1. High-high: area units with high value, where the neighbourhood also has a high

2. High-low: area units with high value, where the neighbourhood has a low value.

3. Low-low: area units with low value, where the neighbourhood also has a low value.

4. Low-high: area units with low value in which the neighbourhood has a high value.

The odd-numbered groups show a positive autocorrelation, while the even-numbered groups a negative one.

Of the local spatial autocorrelation indices, it is highly appropriate to choose a Local Moran I to search for spatially outlying values. Specifically, it shows where the high-low 
values are grouped in the space (HH-LL), and where those territorial units are, which are significantly different from their neighbours (HL-LH). In this case, the isolation and analysis of these four groups is important to ascertain how similar or different these large cities are if compared to their catchment areas. The use of four different clusters also provides an opportunity to examine the issue of whether or not a separate cluster can be isolated around the given city or is it the part of a larger structural unit? If the catchment area essentially forms a separate cluster, a theoretical situation can be assumed in which the cluster emerges like an island from the relatively undeveloped group of settlements. Of course, it will only very rarely be the case, for example, because of the intertwining of the catchment areas.

This latter case may be one reason behind the development of larger spatial units, which are essentially about the merger of hot, as well as cold spots, (hot and cold spots mean the spatial concentration of high or low values).

The calculations were performed on per capita incomes and unemployment rates for 2001 and 2011. It can be said for both indicators that there was no fundamental change in the spatial picture of the clusters, so this study only deals with 2011.

A large area in Northwestern Hungary and the Budapest agglomeration are essentially closely related hot spots (Figure 4), where the group of those municipalities, which are more advanced than the average, is closely linked. In the corridors of motorways M6 and M3, several southern and eastern Hungarian settlements are also connected to this. There are also county seats in this block: Szombathely, Veszprém, Tatabánya; the catchment areas of these settlements are not separate from the broader environment, but essentially melt into it. A somewhat different situation can be observed in the case of Miskolc, Pécs and Zalaegerszeg. Smaller hot spots are also clearly outlined here; that is, the centre and its narrow catchment area are more advanced than the average, and they are similar to each other. Nyíregyháza and Debrecen should be distinguished among the county seats, as both of them can be regarded as spatial outliers (i.e. a settlement of spatially outstanding value) that is, such a central municipality, which is more advanced than the national average, but very sharply different from the developmental situation of its environment. Concerning the other county seats, a significant relationship cannot be established between the centre and its catchment area. It means that the changes in the degree of proximity (measured by road accessibility between municipalities) and the per capita income of neighbouring municipalities are not significantly correlated with each other.

As for the unemployment rate, only minor differences can be seen compared to the preceding ones (Figure 5). The group of the best areas, that is, the cold spot, which has low values and is different from its environment, also covers roughly similar areas, but it is true that in this case the range of these regions is separated into two groups, one of them covers Budapest and its wider agglomeration, and the other a significant part of Györ-Moson-Sopron and Vas counties.

Szeged, Pécs and Szombathely together with their catchment areas are also considered to be cold spots. The other towns of county rank do not show any significant relationship with their neighbours and their catchment areas in respect of the unemployment rate. 
The local similarity of the per capita income, 2011

Figure 4

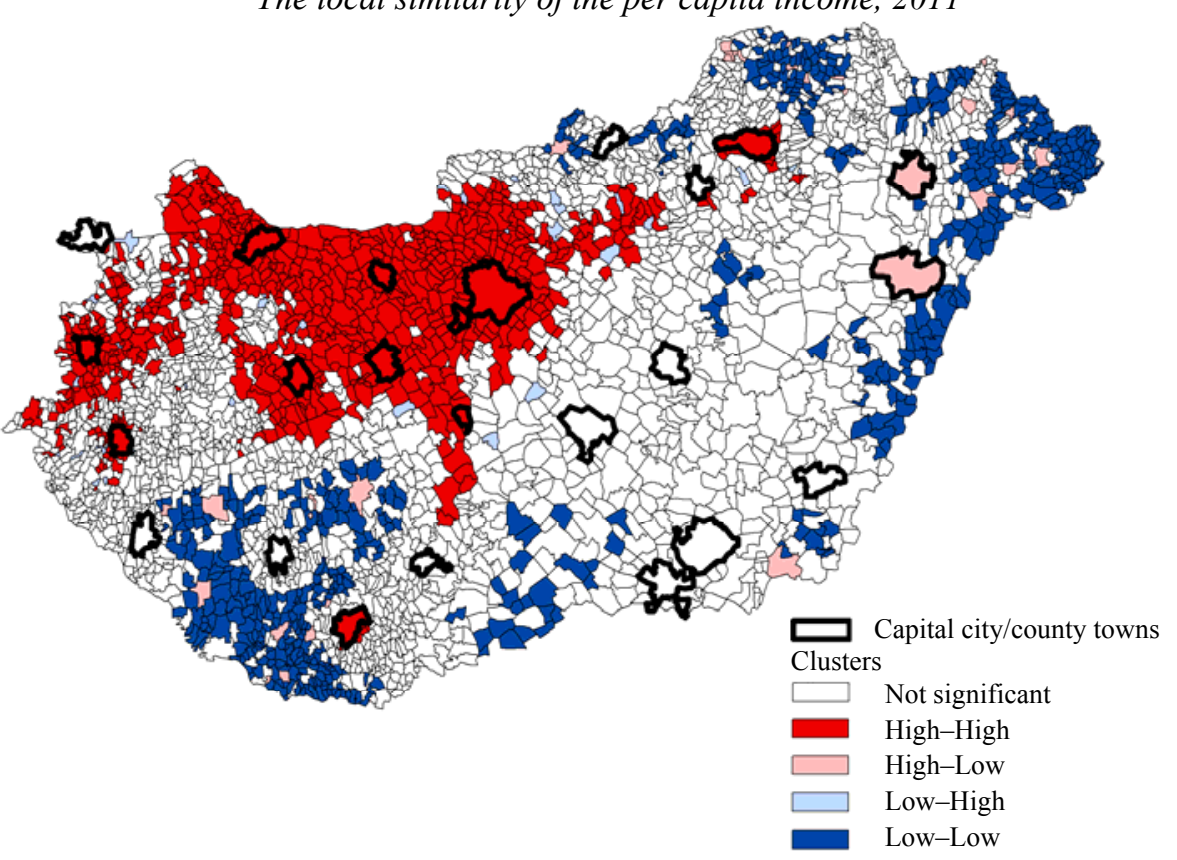

The local similarity of the unemployment rate, 2011

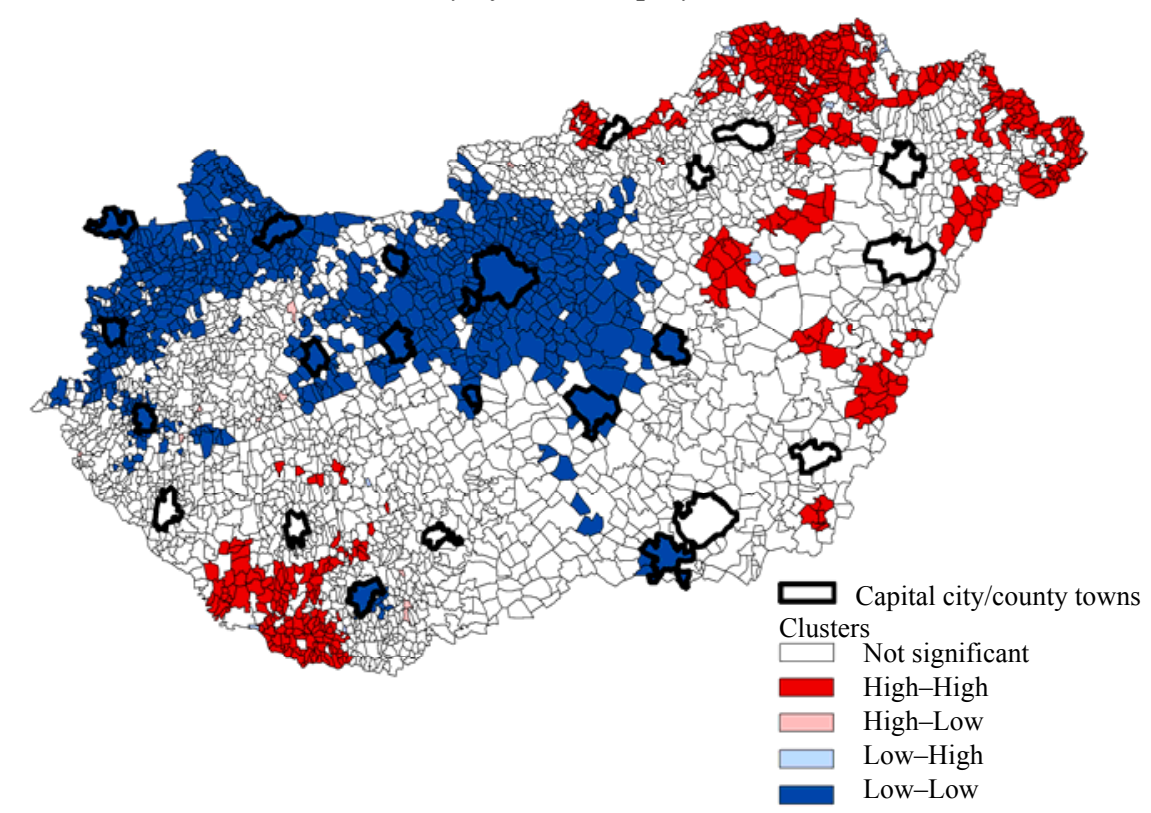


Figures 4 and 5, showing the data of Northwest Hungary and the Budapest agglomeration, are suitable to evoke the thoughts of Enyedi (2012), who said that nowadays traditional urban agglomerations, which are made up by a central city as well as adjoining small towns and villages, are replaced by wide areas of metropolitan regions, where the big city remains the core, but it also has several sub-centres which are closely related due to the functional division of labour. "Such a metropolitan region is emerging around Budapest through the expansion of the Budapest agglomeration" (this region's peripheral towns are Tatabánya, Székesfehérvár, Kecskemét, Szolnok and Gyöngyös) (Enyedi 2012, p. 17).

The scientific literature does not recommend comparing Local Moran's I indices with each other (Dusek 2013), unless the concerned indicators were calculated primarily using the same territorial matrix. At present, this is the case as between 2001 and 2011 only the secession of a few settlements modified the settlement matrix. Therefore, during the following analysis, the unstandardised Local Moran I indices will be compared with each other disregarding those significance levels, which were taken into account while determining the clusters.

Table 3

Unstandardised Local Moran I indices, 2001-2011

\begin{tabular}{|c|c|c|c|c|}
\hline \multirow{2}{*}{ Capital city, county towns } & \multicolumn{2}{|c|}{ Per capita income } & \multicolumn{2}{|c|}{ Unemployment rate } \\
\hline & 2001 & 2011 & 2001 & 2011 \\
\hline Békéscsaba & -0.023 & -0.108 & 0.2006 & -0.165 \\
\hline Budapest & 8.254 & 4.792 & 1.2058 & 4.564 \\
\hline Debrecen & -0.640 & -0.276 & 0.0407 & -0.434 \\
\hline Dunaújváros & 4.249 & 1.819 & 0.5083 & 1.272 \\
\hline Eger & 1.094 & 0.393 & 0.1925 & 0.231 \\
\hline Érd & 3.788 & 2.955 & 0.9607 & 2.691 \\
\hline Győr & 5.052 & 3.136 & 0.8086 & 2.969 \\
\hline Hódmezővásárhely & 0.303 & 0.047 & 0.3227 & 0.027 \\
\hline Kaposvár & 0.236 & 0.094 & 0.2476 & 0.019 \\
\hline Kecskemét & 0.002 & 0.082 & 0.4095 & -0.002 \\
\hline Miskolc & 0.438 & 0.545 & 0.0021 & 0.446 \\
\hline Nagykanizsa & -0.053 & 0.218 & 0.2140 & 0.135 \\
\hline Nyíregyháza & -0.775 & -0.364 & 0.0192 & -0.480 \\
\hline Pécs & 0.208 & 0.492 & 0.4505 & 0.427 \\
\hline Salgótarján & -0.442 & -0.246 & 0.0818 & -0.339 \\
\hline Sopron & 1.844 & 0.236 & 1.1863 & 0.283 \\
\hline Szeged & 0.040 & -0.062 & 0.4248 & -0.202 \\
\hline Székesfehérvár & 4.312 & 3.382 & 0.6490 & 3.239 \\
\hline Szekszárd & 0.694 & 0.131 & 0.1030 & 0.021 \\
\hline Szolnok & 0.000 & 0.241 & 0.3695 & 0.135 \\
\hline Szombathely & 4.357 & 1.949 & 0.7647 & 1.841 \\
\hline Tatabánya & 1.764 & 1.856 & 0.5324 & 1.757 \\
\hline Veszprém & 4.389 & 2.145 & 0.6047 & 1.994 \\
\hline Zalaegerszeg & 1.852 & 1.218 & 0.6126 & 1.177 \\
\hline
\end{tabular}

Source: Own compilation. 
Concerning per capita income, in 2011, in the case of 19 of the 24 cities, the index was positive, in that, to some extent, the development of the centre was similar to that of the catchment area. In 2011, compared to 2001, the value of this indicator fell in 13 settlements, that is, to some extent, there was a fall in the similarity between the centre and its environs. This indicates the weakening of the agglomeration processes. It can be seen that the sharpest declines were mainly detected at those Local Moran's I indices, which were in the positive range; despite the fact that the positive autocorrelation persists, its strength is considerably weakened. In 2011, among the examined settlements, Budapest was the most similar to its environment, while Nyíregyháza was the most different.

In respect of the unemployment rate, in 2011, a positive Local Moran I index was seen in 18 of the 24 cities, but by 2011, compared to 2001, there were also 13 such cases, where the value of the indicator fell. Also in this case, those centres were affected by the positive changes, which were similar to their environment, i.e. in the relationship of the centre and its catchment area, the unemployment situation became more similar than ever before. In 2011 - similarly to per capita incomes - Budapest and Nyíregyháza represented the two extreme values.

\section{Summary}

Our calculations revealed that although in recent times the catchment areas of major cities overtook their centres in terms of the growth of per capita income, fundamentally they remained less developed than their centres. Looking at the unemployment rate, the situation is already different in so far that the centres are usually in a better position than the surrounding areas, but in recent times they were often characterised by more unfavourable processes than their hinterlands.

Compared to the national average, the state of the competitiveness reflects the basic territorial development conditions as those cities and their catchment areas proved to be competitive which were in relatively well-developed counties, while in the underdeveloped counties the competitive centre and the less-competitive catchment area was the most frequent matching. In particularly unfavourable cases, both units are competitively disadvantaged. Recent changes showed only a few examples where both the centre and its catchment area were characterised by advantageous competitive processes. Most frequently, the catchment area is in a competitively advantaged position, while its centre is competitively disadvantaged.

The papers autocorrelation analysis shows that large cities and their catchment areas, in many cases, are part of a large structural unit - in this case it is also an area of northwest Hungary involving the Budapest agglomeration - and there are only a few cases where they are clearly separated as a stand-alone unit from the surrounding settlements.

Thus, the results of the study clearly indicate that the economic potential of the metropolitan areas in Hungary (in various cities and their catchment areas) is quite different. There are such areas where the economic fundamentals of a mutual benefit based development are clearly detectable, but in most cases this is not typical. The 
economic status of either one party or the other or even both of them hinders the unfolding of a healthy development.

\section{REFERENCES}

Adam, B. (2003): Spatial policies for metropolitan regions - identity, participation and integration. European Planning Studies 11 (6): 739-747.

Anselin, L. (1995): Local indicators of spatial association-LISA. Geographical Analysis 27 (2): $93-115$.

Bálint Lajos (2011): A születéskor várható élettartam nemek szerinti térbeli különbségei. Területi Statisztika 51 (4): 386-404.

Beluszky Pál (1970): A falu-város közötti kapcsolatok vizsgálati módszerei, I rész. Területi Statisztika 20 (4): $368-380$.

Benedek József (2000): A társadalom térbelisége és térszervezése. Risoprint, Kolozsvár.

Bodor Norbert - Pénzes János (2012): Eger komplex vonzáskörzetének dinamikai vizsgálata. Tér és Társadalom 26 (3): 30-47.

Dusek Tamás (2013): A területi statisztika egyes térparamétereket használó elemzési eszközei. Habilitációs értekezés, Győr.

Egedy Tamás (2012): A gazdasági válság hatása a nagyvárosok versenyképességére Magyarországon. Földrajzi Közlemények 136 (4): 420-438.

Dunford, M. - Perrons, D. (1994): Regional identity, regimes of accumulation and economic development in contemporary Europe. Transactions of the Institute of British Geographers 19 (2): 163-182.

Enyedi György (2012): Városi világ. Akadémiai Kiadó, Budapest.

Forray R. Katalin - Híves Tamás (2009): Az iskolázottság, a foglalkoztatottság és az ingázás területi összefüggései. Az iskolázottság, a foglalkoztatottság és az ingázás területi összefüggései. Szociológiai Szemle 19 (2):42-59.

Getis, A. - Ord, J. K. (1996): Local spatial statistics: an overview. In: Paul Longley - Michael Batty: Spatial Analysis: Modelling in a GIS Environment. pp. 261-277. GeoInformation International: Cambridge, England.

Giuliano, G. - Small, K. A. (1993): Is the Journey to Work Explained by Urban Structure? Urban Studies 30 (9): 1485-1500.

Győri Róbert (2000): A Kisalföld kereskedelmi vonzáskörzet-rendszere 1925-ben. Tér és Társadalom 14 (23.): 303-309.

Haggett, P. (2006): Geográfia Globális szintézis. Typotex Kiadó, Budapest.

Hajdú Zoltán (1994): A Dél-Dunántúl középfokú vonzáskörzeteinek területi rendje: (Egy felmérés eredményei és tanulságai a vonzáskörzet-kutatások szempontjából). Tér és Társadalom 8 (1-2): 5-24.

Hardi Tamás (2008): A határtérség térszerkezeti jellemzői. Tér és Társadalom 22 (3): 3-25.

Hoggart, K. (2012): The City's Hinterland. Dynamism and Divergence in Europe's Peri-Urban Territories. Ashgate, Aldershot.

Kiss János Péter - Bajmócy Péter (2001): Városi funkciójú központok és elméleti vonzáskörzeteik az Alföldön. Tér és Társadalom 15 (1): 65-89.

Kiss János Péter (2008). A területi jövedelemegyenlötlenségek strukturális tényezői Magyarországon. PhDdisszertáció, Szeged.

Kovács Tibor (2002): Prológ a statisztikai kistérségi területbeosztás felülvizsgálatához. Területi Statisztika 42 (3): 203-209.

Kovács Tibor - Tóth Géza (2003): Agglomerációk, településegyüttesek a magyar településrendszerben. A területbeosztás 2003. évi felülvizsgálatának eredményei. Területi Statisztika 43 (4): 387-391.

Kovács Zoltán (1987): Kereskedelmi centrumok és vonzáskörzetek Heves megyében. Földrajzi Értesitő 36 (34.): $253-272$.

Kovács Zoltán (1990): A határ menti területek központhálózatának átalakulása az első világháború utántól napjainkig. Földrajzi Közlemények 114 (1-2.): 3-16.

Lengyel Imre (2003): Verseny és területi fejlődés: térségek versenyképessége Magyarországon. JATEPress, Szeged.

Lőcsei Hajnalka (2004): A vidéki városi agglomerációk fejlődési pályája. In: Térségi és települési növekedési pályák Magyarországon. pp. 75-90. Regionális Tudományi Tanulmányok 9. ELTE Regionális Földrajzi Tanszék - MTA-ELTE Regionális Tudományi Kutatócsoport, Budapest.

Lőcsei Hajnalka (2010a): Területi növekedési pályák Magyarországon, 1990-2008. PhD-disszertáció, Budapest.

Lőcsei Hajnalka (2010b): A gazdasági világválság hatása a munkanélküliség területi egyenlőtlenségeire. In: Fazekas Károly - Molnár György (szerk.) (2010): Munkaerőpiaci tükör 2010. A válság 
munkapiaci hatásai. pp. 126-141. MTA Közgazdaságtudományi Intézet, Országos Foglalkoztatási Közalapítvány, Budapest.

Mokos Béla (1998): Budapest vonzáskörzetének munkaerő-piaci térszerkezete. Területi Statisztika 38 (6): $487-$ 509.

Muller. E. K. (1977): Regional urbanization and the selective growth of towns in North American regions. Journal of Historical Geography 3 (1): 21-39.

Nemes Nagy József (2004): Új kistérségek, új városok. Új versenyzők? Regionális Tudományi Tanulmányok 9. Eötvös Loránd Tudományegyetem Regionális Földrajzi Tanszék - Magyar Tudományos Akadémia - ELTE Regionális Tudományi Kutatócsoport. Budapest.

Pénzes János (2005): Városi vonzásközpontok vizsgálata az Észak-alföldi régióban. In: Süli-Zakar István (szerk.): „Tájak - Régiók - Települések” Tisztelgés a 75 éves Enyedi György akadémikus előtt. pp. 160-165., Debrecen.

Pénzes János (2013): A foglalkoztatottság, az ingázás és a jövedelmi szint összefüggései Északkelet- és Északnyugat-Magyarországon. Területi Statisztika 53 (3): 202-224.

Schuh, B.- Sedlacek, S. (2002): Problem Centred City-Hinterland Management - A Scientific and Policy Approach. $42^{\text {nd }}$ Congress of the European Regional Association (ERSA), Dortmund.

Szalkai Gábor (2010): Várostérségek lehatárolása a közúti forgalom nagysága alapján a magyar határok mentén. Tér és Társadalom 24 (4): 161-184.

Sütő Attila (2008): Város és vidéke rendszerek és típusaik Magyarországon. Falu Város Régió 15 (3): 51-64

Szirmai Viktória /ed/. (2007): Social Inequalities in Urban Areas and Globalization. The Case of Central Europe. Based on the Results of the Project 'Urban Areas, Socio-spatial Inequalities and Conflicts - The Socio-spatial Factors of European Competitiveness'. Centre for Regional Studies of Hungarian Academy of Sciences, Pécs.

Szirmai Viktória (2009): A várostérségi versenyképesség társadalmi tényezői. Dialóg Campus Kiadó, Pécs - Budapest. Taylor, P. (2004): World city network: a global urban analysis. Routledge, London.

Tóth Géza (2003): Területi autokorrelációs vizsgálat a Local Moran I módszerével Tér és Társadalom 27 (4): 39-49.

Tóth Géza - Kincses Áron (2011): A mai magyarországi bevándorlás térbeli autokorreláltsága. Földrajzi Közlemények 135 (1): 83-91. 
Annex

Competitiveness of the studied settlements and their catchment areas, 2011

\begin{tabular}{|c|c|c|c|}
\hline \multirow{2}{*}{ Capital city, county towns } & \multirow{2}{*}{ Central settlement } & 30-minute & 45-minute \\
\hline & & \multicolumn{2}{|c|}{ catchment areas } \\
\hline Békéscsaba & 0010 & 0011 & 0011 \\
\hline Budapest & 1110 & 1110 & 1110 \\
\hline Debrecen & 1111 & 0001 & 0001 \\
\hline Dunaújváros & 1111 & 1111 & 1110 \\
\hline Eger & 1110 & 0001 & 0001 \\
\hline Érd & 1101 & 1110 & 1110 \\
\hline Győr & 1110 & 1011 & 1011 \\
\hline Hódmezővásárhely & 0010 & 0010 & 0000 \\
\hline Kaposvár & 0010 & 0001 & 0001 \\
\hline Kecskemét & 1110 & 0001 & 1100 \\
\hline Miskolc & 1100 & 0001 & 0001 \\
\hline Nagykanizsa & 1011 & 0001 & 0011 \\
\hline Nyíregyháza & 1011 & 0001 & 0001 \\
\hline Pécs & 1100 & 0001 & 0001 \\
\hline Salgótarján & 0001 & 0000 & 0001 \\
\hline Sopron & 0010 & 0010 & 1011 \\
\hline Szeged & 1110 & 0001 & 0001 \\
\hline Székesfehérvár & 1110 & 1111 & 1110 \\
\hline Szekszárd & 1111 & 0001 & 0001 \\
\hline Szolnok & 1110 & 0001 & 0001 \\
\hline Szombathely & 1110 & 1011 & 0011 \\
\hline Tatabánya & 1111 & 1110 & 1110 \\
\hline Veszprém & 1110 & 1011 & 1011 \\
\hline Zalaegerszeg & 1110 & 0011 & 0011 \\
\hline
\end{tabular}


Competitiveness of the studied settlements and their catchment areas, 2001/2011

\begin{tabular}{|c|c|c|c|}
\hline \multirow{2}{*}{ Capital city, county towns } & \multirow{2}{*}{ Central settlement } & 30-minute & 45-minute \\
\hline & & \multicolumn{2}{|c|}{ catchment areas } \\
\hline Békéscsaba & 0100 & 1111 & 1111 \\
\hline Budapest & 0000 & 1110 & 1110 \\
\hline Debrecen & 0110 & 1111 & 1011 \\
\hline Dunaújváros & 0000 & 1111 & 0000 \\
\hline Eger & 0100 & 1111 & 1111 \\
\hline Érd & 1110 & 0000 & 0000 \\
\hline Győr & 0000 & 1100 & 1101 \\
\hline Hódmezővásárhely & 0000 & 0100 & 1100 \\
\hline Kaposvár & 0000 & 1011 & 1001 \\
\hline Kecskemét & 0100 & 1111 & 0000 \\
\hline Miskolc & 1110 & 1111 & 1011 \\
\hline Nagykanizsa & 0000 & 1111 & 1011 \\
\hline Nyíregyháza & 1110 & 1011 & 1011 \\
\hline Pécs & 0100 & 1111 & 1111 \\
\hline Salgótarján & 0000 & 1111 & 0011 \\
\hline Sopron & 0000 & 0001 & 0000 \\
\hline Szeged & 0100 & 1111 & 1111 \\
\hline Székesfehérvár & 0000 & 1100 & 0000 \\
\hline Szekszárd & 0100 & 0101 & 1101 \\
\hline Szolnok & 0000 & 1111 & 1111 \\
\hline Szombathely & 0000 & 0001 & 0001 \\
\hline Tatabánya & 1100 & 1100 & 0000 \\
\hline Veszprém & 0100 & 1101 & 0101 \\
\hline Zalaegerszeg & 0100 & 1101 & 0001 \\
\hline
\end{tabular}

